\title{
SHORT COMMUNICATION（症例報告）
}

\section{Cyclosporine Aの有効血中濃度が示唆された 赤芽球瘵の 1 症例}

$\begin{array}{lll}\text { 中 村 敏 明*1 } & \text { 平 木 優 子*1 福 島 紀美江 }{ }^{* 1} \\ \text { 政 田 幹 } \text { 夫 }^{* 1} \text { 上 田 孝 典*2 } & \end{array}$

（受付：1998 年 2 月 19 日)

\author{
Toshiaki NAKAMURA *1 Yuko HIRAKI*1 \\ Kimie FUKUSHIMA *1 Mikio MASADA*1 \\ and Takanori UEDA*2 \\ ${ }^{* 1}$ Department of Hospital Pharmacy, Fukui Medical University \\ 23 Shimoaizuki, Matsuoka-cho, Yoshida-gun, Fukui 910-1193, Japan \\ *2 First Department of Internal Medicine, Fukui Medical University
}

Cyclosporine A (CyA), an immunosuppressive drug, has shown a potency in pure red cell aplasia (PRCA). However, the effective blood level is not known in PRCA treatment. In a PRCA patient (53-year-old male) who responded to CyA, we carefully monitored CyA trough levels over a 4-year period. In the first 6 months, the hemoglobin level was about $11 \mathrm{~g} / \mathrm{dl}$ and the CyA trough level was over $150 \mathrm{ng} / \mathrm{ml}$; the dose of CyA was then tapered to prevent renal toxicity. The trough level was controlled between 100 and $150 \mathrm{ng} / \mathrm{ml}$, and he remained in continuous remission for the subsequent year. However, after that time, the hemoglobin level gradually decreased and PRCA recurred. We then increased the CyA trough level to over $150 \mathrm{ng} / \mathrm{ml}$ and his anemia improved. This case report illustrates that a CyA trough level of at least $150 \mathrm{ng} / \mathrm{ml}$ is necessary to maintain remission.

Key words : pure red cell aplasia, cyclosporine A, trough level, hemoglobin

*1 福井医科大学医学部附属病院薬剤部 $\bar{\top} 910-1193$ 福井県吉田郡松岡町下合月 23

*2 福井医科大学医学部第一内科 


\section{はじめに}

赤芽球疼 (PRCA) は再生不良性貧血の 1 亚型と 位置づけられ，造血細胞中の顆粒球系および骨髄 巨核球系細胞には異常が認められず，赤芽球系細 胞にのみ選択的に障害を受け，貧血症状を示す症 候群である ${ }^{1)}$. 病因として免疫学的機序が関与し ていることが知られており ${ }^{2)}$ ，ステロイドパルス 療法，抗リンパ球グロブリン療法，抗胸腺細胞グ ロブリン療法や cyclosporine A (CyA) を用いた 免疫抑制療法が試みられている3 PRCA に対して適応拡大になった CyA は，他の 免疫抑制療法に反応しなかった多剤抵抗例におい ても有効な場合が多く，有用な薬剤である ${ }^{4,5)}$. し かし，その投与に際しては体内動態の個体内およ び個体間変動が大きく，また腎障害などの重篤な 副作用も発現するため投与設計が難しく，副作用 防止のために血中薬物濃度モニタリング (TDM) を行いながらトラフ濃度を $200 \mathrm{ng} / \mathrm{ml}$ 以下に維 持するように投与量を調節している.

しかしながら，PRCA に対する CyA の有効濃 度については明確になっておらず，副作用を防止 するために TDM を行っているのが現状である。

今回，CyAにより治療されている PRCA 患者 において，長期間 CyA トラフ濃度をモニタリン グしたところ, 明確な有効濃度が認められた症例 を経験したので報告する。

\section{患者背景}

患者：53 歳，男性，身長 $160 \mathrm{~cm}$ ，体重 $56 \mathrm{~kg}$. 経過：1981 年 10 月に貧血を指摘され, 造血剤 投与されるが反応せず。 1989 年 3 月に PRCA と 診断されるまでに, prednisolone, mepitiostane, metenolone を順次投与するが, 一過性のへモグ ロビン $(\mathrm{Hb})$ 上昇を認めるのみであった。また， 1989 年 3 月以降も ubenimex, エリスロポエチン, GM-CSF, danazol, $\gamma$-グロブリン大量療法を試み たが無効で，新鮮洗浄赤血球の輸血により $\mathrm{Hb}$ を 7〜 9 g/dl に維持していた. 1991 年 1 月より CyA による治療を開始した。開始直前, 骨髄正形成, 赤芽球 $0.6 \%$, 末梢血赤血球数 281 万 $/ \mu 1, \mathrm{Hb} 8.7$ $\mathrm{g} / \mathrm{dl}$, 網状赤血球 $<1 \%$ ，白血球数 $6400 / \mu 1$, 血小 板数 32.9 万/ $\mu 1$ であったが, $\mathrm{CyA}$ 投与 2 力月後に は末梢血赤血球数約 290 万 $/ \mu 1, \mathrm{Hb} 9.3 \mathrm{~g} / \mathrm{dl}$, 網 状赤血球 $4 \%$ と改善を認め, 以後輸血を全く必要 としなくなった。

\section{方 法}

CyA トラフ濃度は, 1992 年 2 月までは SRL 社 に依頼し，それ以降は本院薬剤部において全血中 $\mathrm{CyA}$ 濃度をモノクローナル抗体およびポリク ローナル抗体を用いて蛍光偏光免疫測定法 (FPIA：TDX，ダイナボット株式会社，東京)で 測定した。各種臨床検査值および CyA トラフ濃 度を経時的に追跡調查し, CyA の有効濃度につい て検討した. CyA の投与はサンディミュンカプセ ルを朝，夕2 回に分けて食後に投与した.

\section{結果}

薬剂部で測定を行った 1992 年 3 月以降の投与 量およびCyAトラフ濃度の経時変化を Fig. 1 (a), (b) に示した。投与量の変動に伴った CyA トラ フ濃度が得られており，血中濃度コントロールは 良好であった。当初 $300 \mathrm{mg} / \mathrm{day}$ の投与量でコン トロールされていたが，十分な臨床効果も認めら れており，また CyA トラフ濃度が $290 \mathrm{ng} / \mathrm{ml}$ と 高值を示したため，徐々に減量を開始した. 1993 年 1 月以降 $150 \mathrm{mg} / \mathrm{day}$ の投与量で 18 力に 渡って約 100〜 $150 \mathrm{ng} / \mathrm{ml}$ の安定した CyA トラ フ濃度が得られた. 1994 年 8 月に再発が認められ たため, $150 \mathrm{mg} /$ day から $300 \mathrm{mg} /$ day へ増量し た.

この間の臨床効果の指標として, $\mathrm{Hb}$ 值と網状 赤血球の割合を Fig. 1 (c)，(d) に示した. 網状赤血 球は CyA トラフ濃度の上昇と対応した増加傾向 が認められたが，1993 年 8 月から 1994 年 8 月に かけては非常に大きな変動を示した.また, $\mathrm{Hb}$ 值 は 1994 年 1 月までは 10 12 g/dl で安定してい たが，それ以降緩やかな減少傾向を示しはじめ, 1994 年 8 月には $7 \mathrm{~g} / \mathrm{dl}$ にまで低下し再発と診断 された.その後, CyA の増量によって再び増加し, 以降 11〜 $12 \mathrm{~g} / \mathrm{dl}$ の安定した值を推移した。 
(a)

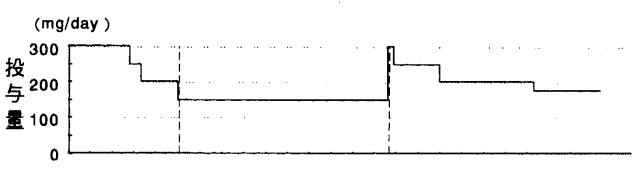

(b) $(\mathrm{ng} / \mathrm{ml})$

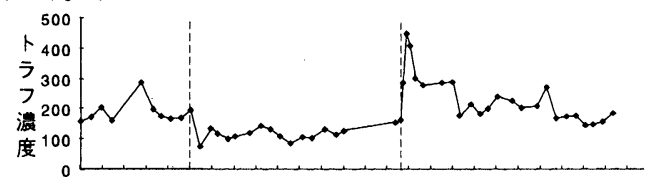

(c)

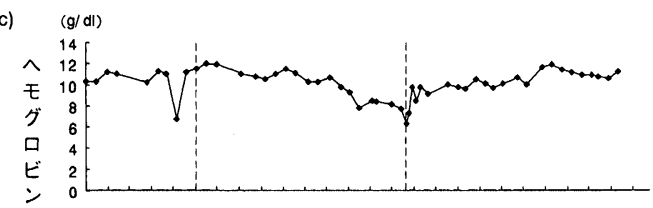

(d)

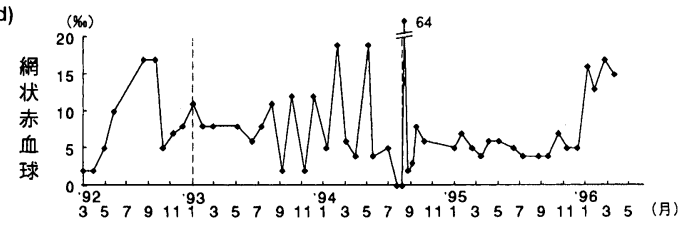

Fig. 1 CyA のコントロール状況と臨床効果
(a) 投与量

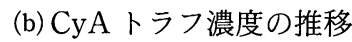
(c) $\mathrm{Hb}$ 值の推移
(d) 網状赤血球分率の推移

また, 臨床検査值として GOT, GPT, 総ビリル ビン值拉よび BUN，クレアチニン值の経過を示 した(Fig. 2). GOT，GPT，総ビリルビン值には とくに変化は認められなかった。これに対して, クレアチニン值は $0.9 \mathrm{mg} / \mathrm{dl}$ で安定していたが, 1994 年 8 月の増量時を境に約 $1.2 \mathrm{mg} / \mathrm{dl}$ にまで 上昇, BUN 值も同様に 15 20 mg/dl であったも のが, 徐々に増加したが約 $25 \mathrm{mg} / \mathrm{dl}$ で落ち着い た.

\section{考 察}

ステロイド抵抗性の PRCA に対し, CyA の投 与が有効であった症例はいくつか報告されてい $3^{4,5)}$. 今回著者らも多剤抵抗性の PRCA に対し て, CyA の投与を試みたところ反応性は良好で, 輸血を全く必要としなくなった。そこで, 副作用 を予防するために十分な臨床効果を確認した後
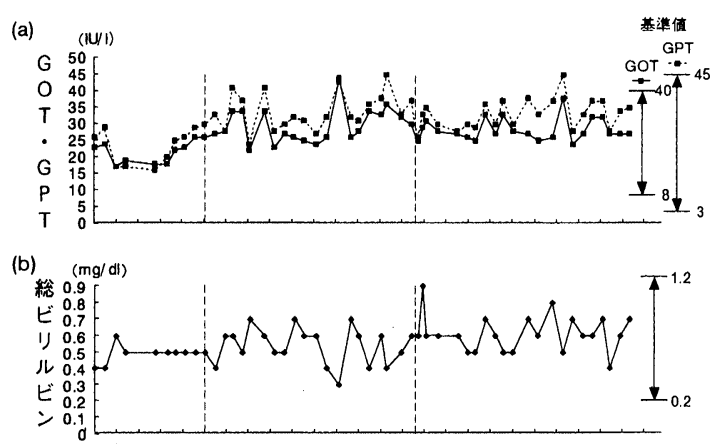

(c)
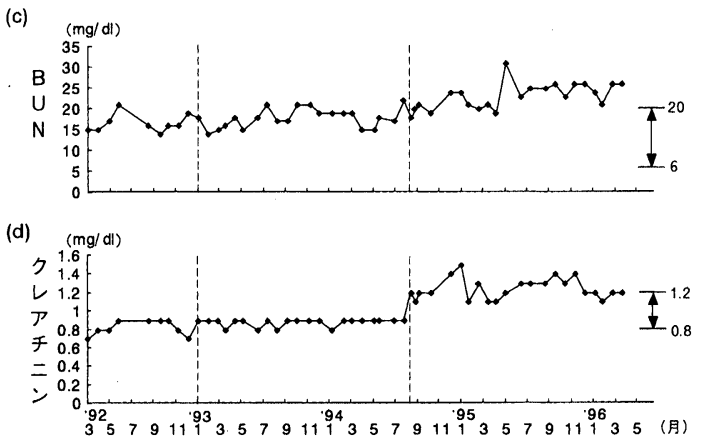

Fig. 2 臨床検査值の推移

(a) GOT, GPT
(b) 総ビリルビン
(c) BUN
(d) クレアチニン

徐々に $\mathrm{CyA}$ 投与量を減量量, トラフ濃度を 100 150 ng/ml にコントロールしながら寛解維 持を試みた。約半年後から徐々にへモグロビン值 の低下傾向が認められ，その 1 年後には再発を認 めた. CyA 投与中止後の再発については, 投与中 止から再発までの期間は 8 力月と比較的長期間の 寛解が得られた報告がある7). 今回の症例では, CyA を継続していたにもかかわらず，約 18 月 後に再発した。このことから, CyA を $100 \mathrm{ng} / \mathrm{ml}$ のトラフ濃度で維持することは再発を予防するの に十分な濃度ではなかったものと考えられる。し かし, 長期間にわたり再発が認められなかったこ とから, CyA を低濃度で維持することが全く無効 であったとは断言できない.そこで, CyA トラフ 濃度と $\mathrm{Hb}$ 值の変動をプロットしたところ, その 経時変化はヒステリシスループを示した (Fig. 3) ので，それを元に PRCA 再発予防に対する CyA 


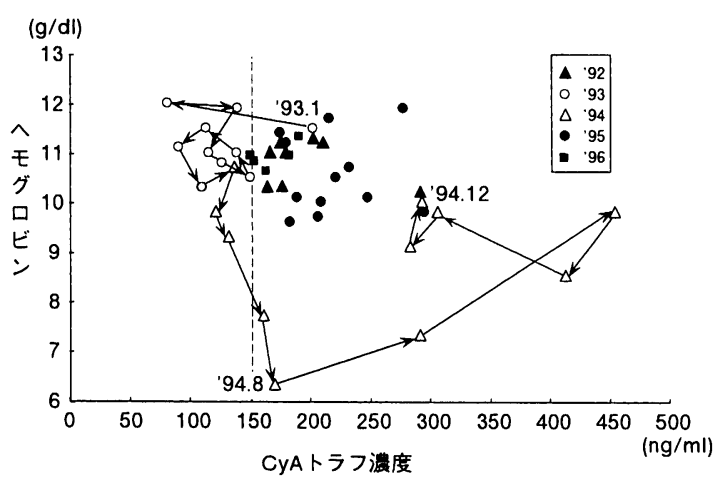

Fig. 3 ヒステリシスループによるCyA トラフ 濃度とへモグロビン值の評価

有効濃度を検討した。

CyA トラフ濃度が $150 \mathrm{ng} / \mathrm{ml}$ 末満に低下した 期間において，一時良好なコントロール状況に思 えたが, 全体的にみると CyA トラフ濃度の值に かかわらず $\mathrm{Hb}$ 值は低下傾向を示した。 とくに， 100 150 ng/ml のトラフ濃度の期間が約 1 年間 経過した時点で急激に $\mathrm{Hb}$ 值の低下が認められ, CyA 投与による造血能の改善が不十分であった。 これに対して, $150 \mathrm{ng} / \mathrm{ml}$ 以上の期間では安定し た臨床効果が得られており，これらのことからこ の症例における PRCA 再発予防に対する CyA ト ラフ濃度の有効濃度は $150 \mathrm{ng} / \mathrm{ml}$ と推定した。 そ の後, CyA トラフ濃度が $150 \mathrm{ng} / \mathrm{ml}$ 以下にならな いように TDM を行うことによって，2 年以上の 長期にわたって寛解が維持されている. また，こ の間の副作用もとくに重篤なものは認められてい ない. ただ，寛解導入のために CyA を増量した際 に血清クレアチニン值が $0.9 \mathrm{mg} / \mathrm{dl}$ から $1.2 \mathrm{mg} /$ $\mathrm{dl}$ に増加しており, CyA 濃度の上昇に伴う腎機能 障害と考えられた。しかし, CyA の減量によりそ れ以上の悪化は認められていない.今回は外来診 療で再寛解導入を行ったためきめ細かな TDM が行えず，トラフ濃度が $300 〜 400 \mathrm{ng} / \mathrm{ml}$ の期間
が持続したことが腎機能の悪化につながったと考 えられるため, 外来診療で寛解導入を行う際には, 急激な増量は避け, 血中濃度を確認しながら慎重 に増量することが重要と考える。

PRCA は症例数が少なく，また CyA の個体間 変動が大きいため, 現在 PRCA に対する CyA の 一般的な有効濃度や体内動態パラメータが求めら れておらず，ポピュレーション解析が行えない. こういった薬剤の TDM を行う際には，今回の症 例のように一見寛解期にあると考えられる時期に おいても, CyA のトラフ濃度と $\mathrm{Hb}$ 值との関係が ヒステリシスループを描くことを考慮し，個々の 症例について注意深く追跡することが重要と考え る. 今後, 同様の症例を増やすことによって，一 般的な有効濃度が明らかになることを期待する。

\section{文献}

1) Raghavacher, A. : Pure red cell aplasia. review of treatment and proposal for a treatment strategy. Blut, $61: 47-51$ (1990).

2）新国公司, 高橋益広：Pure red cell anemia の発症 機序. Immunohaematology, 12:439-444 (1990).

3）王 伯銘, 平澤 晃: 赤芽球痔に対するシクロスポ リン療法。医学のあゆみ, 151：421-424 (1989).

4) Means, Jr. R. T., Sessypris, E. N. and Krantz, S. B. : Treatment of refractory pure red cell aplasia with cyclosporine A. disappearence of IgG inhibitor associated with clinical response. Br. J. Haematol., 78 : 114-119 (1991).

5) Tötterman, T. H., Höglund, M., Bengtsson, M., et al. : Treatment of pure red-cell aplasia and aplastic anaemia with ciclosporin : long-term effects. Eur. J. Haematol., 42:12-133 (1989).

6) Schrezenmeier, H., Schlander, M., Murayama, K., et al. : Cyclosporin A in aplastic anemia-report of a workshop. Ann. Hematol., 65 : 33-36 (1992).

7) Porwit, A., Panayotides, P., Mansson, E., et al. : Cyclosporine A treatment in four cases of aplastic anemia. Blut, 54:73-78 (1987). 